\title{
Exocrine pancreatic insufficiency: accuracy and clinical value of the uniformly labelled ${ }^{13} \mathrm{C}$-Hiolein breath test
}

\author{
B Lembcke, B Braden, W F Caspary
}

\begin{abstract}
Background and Aims-The ${ }^{13} \mathrm{C}-\mathrm{Hiolein}$ breath test $\left(98 \%\right.$ [U- $\left.{ }^{13} \mathrm{C}\right]$ labelled long chain triglyceride mixture (highly labelled triolein) was evaluated as a non-invasive, non-radioactive test for exocrine pancreatic insufficiency. Accuracy and clinical validity were examined with reference to both the secretin pancreozymin test and faecal fat analysis.

Methods-A secretin pancreozymin test and faecal fat analysis were performed in 46 patients, 30 with exocrine pancreatic insufficiency and 16 with normal pancreatic function. In all of these patients and in seven healthy volunteers (controls), a ${ }^{13} \mathrm{C}$-Hiolein breath test was performed using $2 \mathrm{mg} / \mathrm{kg}$ [ $\mathrm{U}-{ }^{13} \mathrm{C}$ ] labelled Hiolein with a standard rice snack $(1 \cdot 5$ g/kg; $25 \%$ fat). ${ }^{13} \mathrm{CO}_{2} /{ }^{12} \mathrm{CO}_{2}$ enrichment in the exhaled breath was measured by isotope ratio mass spectrometry.

Results-In patients with pancreatic steatorrhoea the ${ }^{13} \mathrm{CO}_{2}$ response was below the $95 \%$ confidence interval of ${ }^{13} \mathrm{CO}_{2}$ exhalation in the controls. These responses were also diminished $(p<0 \cdot 001)$ compared with patients with impaired lipase output but normal fat excretion and with disease as well as healthy controls. There was a linear correlation between stimulated lipase output and the ratio of lipase output ${ }^{13} \mathrm{CO}_{2}$ response $(r=0.95)$. Among the 40 patients in whom direct pancreatic function testing was clinically indicated, the sensitivity of the ${ }^{13} \mathrm{C}$ Hiolein test for detecting steatorrhoea was $91 \cdot 7 \%$, with a specificity of $85 \cdot 7 \%$.

Conclusions-In patients with pancreatic disease the ${ }^{13} \mathrm{C}$-Hiolein breath test reflects impaired lipase output and indicates decompensated lipolysis. The ${ }^{13} \mathrm{C}$-Hiolein breath test is a convenient alternative to faecal fat analysis.

(Gut 1996; 39: 668-674)
\end{abstract}

Keywords: pancreas, steatorrhoea, breath tests, lipase, triolein, Hiolein, malabsorption.

An ideal non-invasive test for chronic pancreatitis should quantitatively measure exocrine pancreatic function, and should be sensitive enough to detect functional impairment of the pancreas in diseases other than chronic pancreatitis or in old age, even in the absence of morphological alterations. At the same time, the test should be able to determine both the necessity and the success of supplementation with pancreatin. Obviously, no such test is currently available. ${ }^{1}$

Current tests of pancreatic function are cumbersome, invasive, and expensive - for example, the Lundh and the secretin pancreozymin test, neither of which is as yet standardised - or time consuming and dependent on the patient's cooperation (for example, the fluorescein dilaurate test). Analysis of faecal chymotrypsin, elastase 1, or fat may be resented by both patients and technicians. ${ }^{2-4}$

Whereas the secrectin pancreozymin test and the fluorescein dilaurate test correlate with the occurrence of pancreatic steatorrhoea, 56 neither reflect lipolytic activity and lipolysis to an equal degree and the level of lipolysis in particular guides enzyme replacement therapy.

Therefore, most breath tests for the diagnosis of exocrine pancreatic insufficiency attempt to reflect both pancreatic lipolytic activity and impaired lipolysis or pancreatic steatorrhoea. On a 'no touch' principle of function testing and given that radioactivity is not applied, these breath tests for maldigestion of fat can be regarded as successful examples of patient oriented diagnostic procedures.

Breath tests for fat malabsorption using radioactive ${ }^{14} \mathrm{C}$-triolein or a ${ }^{14} \mathrm{C}$-labelled mixed triglyceride as the substrate for lipolysis have been shown to be valid and diagnostically useful methods. ${ }^{7-9}$ Using stable isotopes offers the advantage of being non-radioactive and developments were initiated in this respect to examine these techniques. ${ }^{10-14}$

This is to our knowledge the first study examining the accuracy and clinical value of the ${ }^{13} \mathrm{C}$-Hiolein breath test using a $98 \%$ [U- ${ }^{13} \mathrm{C}$ ] labelled long chain triglyceride mixture (Table I; highly labelled triolein) in patients with exocrine pancreatic insufficiency, mostly due to chronic pancreatitis.

By contrast with the carboxy labelled ${ }^{13} \mathrm{C}$-triolein as a substrate, ${ }^{13} \mathrm{C}$-Hiolein is a mixture of different uniformly ${ }^{13} \mathrm{C}$-labelled triglycerides. This uniform ${ }^{13} \mathrm{C}$ label facilitates monitoring of lipolysis by ${ }^{13} \mathrm{CO}_{2} /{ }^{12} \mathrm{CO}_{2}$ isotope ratio mass spectrometry as the signal is amplified according to the reiterative release of ${ }^{13} \mathrm{CO}_{2}$ during $\beta$-oxidation, thereby allowing the use of tracer doses. ${ }^{13}$

If the ${ }^{13} \mathrm{C}$-Hiolein breath test permitted detection of impaired lipolytic activity in 
TABLE I Fatty acid composition of Hiolein

\begin{tabular}{|c|c|c|}
\hline Fatty acid & Common name & Proportion (\%) \\
\hline $\begin{array}{l}18: 1 \omega-6 \\
16: 0 \omega-6 \\
18: 2 \omega-6 \\
18: 3 \omega-3 \\
18: 0 \omega-6 \\
16: 1 \omega-9 \\
16: 2 \omega-6 \\
16: 3 \omega-3\end{array}$ & $\begin{array}{l}\text { Oleic acid } \\
\text { Palmitic acid } \\
\text { Linoleic acid } \\
\alpha \text {-Linolenic acid } \\
\text { Stearic acid } \\
\text { Palmitoleic acid } \\
\text { No common name } \\
\text { No common name }\end{array}$ & $\begin{array}{r}50 \cdot 6 \\
16 \cdot 9 \\
19 \cdot 6 \\
3 \cdot 0 \\
2 \cdot 3 \\
1 \cdot 8 \\
1 \cdot 4 \\
1 \cdot 2\end{array}$ \\
\hline
\end{tabular}

Analysis of sample lot No 0242 used in this study.

patients with chronic pancreatitis, this would provide a clean and elegant method for diagnosing exocrine pancreatic insufficiency, and for monitoring the efficacy of pancreatic enzyme replacement therapy.

Our investigation was therefore carried out with a special emphasis on the value of the ${ }^{13} \mathrm{C}$-Hiolein breath test to measure lipolytic activity, referring to the secretin pancreozymin test as the gold standard, ${ }^{15}$ as well as pancreatic steatorrhoea, compared with faecal fat analysis, ${ }^{16-18}$ and hence encompassing all degrees of pancreatic dysfunction.

\section{Methods}

\section{PATIENTS}

Forty patients with suspected pancreatic disease and an additional six patients with intestinal causes of malabsorption (coeliac sprue, bacterial overgrowth) underwent a secretin pancreozymin test as an established part of our diagnostic routine function tests. In 16 patients, including all six with intestinal causes of malabsorption, exocrine pancreatic function was normal as determined by the secretin pancreozymin test.

Thirty patients were shown to have exocrine pancreatic insufficiency by an abnormal secretin pancreozymin test. In 22 of these patients, chronic pancreatitis was diagnosed by the clinical course and an abnormal secretin pancreozymin test in addition to an abnormal pancreatogram at endoscopic retrograde cholangiopancreatography (ERCP) or signs of chronic pancreatitis at ultrasonography or computed tomography (CT). Five patients with an abnormal secretin pancreozymin test had pancreatic carcinoma. One patient with exocrine insufficiency had a pancreas divisum and status after biliary pancreatitis, and in two patients the aetiology of the exocrine pancreatic insufficiency remained unexplained. Table II lists the characteristics of the patient groups.

TABLE II Characteristics of the patient groups

\begin{tabular}{lrllll}
\hline Group & $n$ & $\begin{array}{l}\text { Age }(y) \\
(\text { mean }(\text { range) })\end{array}$ & $\begin{array}{l}\text { Sex } \\
(M: F)\end{array}$ & $\begin{array}{l}\text { Faecal fat (g/day) } \\
(\text { mean (SEM)) }\end{array}$ & $\begin{array}{l}\text { Lipase output (U/30 min) } \\
\text { (mean (SEM)) }\end{array}$ \\
\hline I & 12 & $57(40-71)$ & $10: 2$ & $31 \cdot 1(6 \cdot 8)$ & $4016(1371)$ \\
II & 18 & $49(26-69)$ & $15: 3$ & $3 \cdot 3(0 \cdot 3)$ & $40880(4183)$ \\
III & 10 & $44(27-62)$ & $8: 2$ & $4 \cdot 1(0 \cdot 7)$ & $147265(22167)$ \\
IV & 7 & $35(30-48)$ & $3: 4$ & ND & ND \\
V & 6 & $50(29-73)$ & $4: 2$ & $12 \cdot 5(1 \cdot 4)$ & $101761(19183)$ \\
\hline
\end{tabular}

$\mathrm{ND}=$ Not determined.
Group I: pancreatic steatorrhoea

Twelve of the 30 patients with an abnormal secretin pancreozymin test had pancreatic steatorrhoea (faecal fat excretion $>7$ g/day; stimulated lipase output $<10 \%$ of the normal mean $(<12000 \mathrm{U} / 30 \mathrm{~min}$ after cholecystokinin-pancreozymin (CCK-Pz)).

Ten of them had chronic pancreatitis (two with diabetes mellitus), two pancreatic carcinoma (a $5.5 \times 9.8 \mathrm{~cm}$ mass of the pancreatic head (with lymph node involvement) in one, and an extensive carcinoma of the pancreatic body plus tail with involvement of the mesenteric artery and lymph nodes in the other patient).

\section{Group II: exocrine pancreatic insufficiency} without steatorrhoea

These 18 patients had exocrine pancreatic insufficiency (secretin pancreozymin test) without steatorrhoea. Twelve patients in this group had chronic pancreatitis, two had chronic pancreatitis with diabetes mellitus in addition, and three had pancreatic carcinoma (all three with a large tumour mass of the body of the pancreas with lymph node involvement, and in one additionally of the head of the pancreas). Exocrine insufficiency was unexplained in one patient.

\section{Group III: patients with normal exocrine} pancreatic function and without steatorrhoea Among the 10 patients in this group the secretin pancreozymin test and faecal fat excretion were normal. Eight were considered as having functional abdominal pain, one patient had functional diarrhoea (mean stool weight $267 \mathrm{~g} /$ day), and one patient had morphological signs of chronic pancreatitis (ERCP and ultrasonography) without functional impairment (a patient with alcoholic pancreatitis showing pancreatic calcifications, diabetes mellitus (unrelated to pancreatitis), and cirrhosis of the liver).

\section{Group IV: normal controls}

This group consisted of seven healthy volunteers who underwent the Hiolein test for their own curiosity, to gain personal experience with the test, and for helping us with the study. In these subjects (colleagues and laboratory staff), a pancreatic function test and faecal fat analysis was not performed.

\section{Group V: non-pancreatic steatorrhoea (disease controls)}

Six patients with diarrhoea (mean stool weight 458 (SD 102) g/day) and steatorrhoea (range= $9 \cdot 5-18.6 \mathrm{~g} /$ day) of intestinal origin underwent a secretin pancreozymin test (with normal results) which excluded exocrine pancreatic insufficiency.

\section{${ }^{13} \mathrm{C}-$ HIOLEIN BREATH TEST}

Hiolein (Martek Corporation, Columbia, USA) is an algal product with uniformly 
${ }^{13} \mathrm{C}$-labelled triglycerides (derived from ${ }^{13} \mathrm{CO}_{2}$ as the sole atmospheric carbon source for the assimilation process), which comprises a triglyceride mixture with naturally occurring long chain fatty acids (Table I). This substrate is $98 \%$ uniformly labelled $\left[\mathrm{U}-{ }^{13} \mathrm{C}\right]$ thereby facilitating the use of small tracer doses for generating ${ }^{13} \mathrm{CO}_{2}$ abundances in breath that are within the detectable range. ${ }^{13}$

Patients and controls received $2 \mathrm{mg} \mathrm{98 \%}$ $\left[\mathrm{U}-{ }^{13} \mathrm{C}\right]-$ Hiolein $/ \mathrm{kg}$ with a commercial rice snack as the sole meal in the morning after an overnight fast (Yinwa Kabuki rice snack, Gumport, Norderstedt, Germany $(1.5 \mathrm{~g} / \mathrm{kg})$ ). This snack $(25 \%(\mathrm{w} / \mathrm{w})$ fat, $37 \%(\mathrm{w} / \mathrm{w})$ carbohydrates) does not change baseline ${ }^{13} \mathrm{CO}_{2} /{ }^{12} \mathrm{CO}_{2}$ abundance and additionally allows measurement of starch malassimilation indicated by increased breath hydrogen concentrations (rice starch breath hydrogen test) as described. ${ }^{19}$ However, the starch load was only $1 / 3$ of that used by Kerlin et $a l^{19}$ and (therefore) only four patients had a rise of $\mathrm{H}_{2}$ concentrations $>20 \mathrm{ppm}$ after the rice starch meal. These data are not discussed as a measure of pancreatic function. A dose of 200 $\mathrm{ml}$ mineral water was taken with the test meal and additional aliquots were permitted five hours later. The next meal was permitted eight hours after the rice meal.

Basal breath samples were obtained before and at the end of the test meal, which was consumed within 10 minutes. Postprandial breath samples were collected at 30 minute intervals for eight hours and at 60 minute intervals from eight to 12 hours. A final sample was obtained 24 hours after the meal.

The study was performed in accordance with the guidelines of the Helsinki Declaration and the use of ${ }^{13} \mathrm{C}$-Hiolein for purposes of the study was approved by the local ethics committee of the University of Frankfurt.

\section{ISOTOPE RATIO MASS SPECTROMETRY}

Enrichment of ${ }^{13} \mathrm{CO}_{2} /{ }^{12} \mathrm{CO}_{2}$ in breath was measured by continuous flow isotope ratio mass spectrometry using a Tracermass mass spectrometer (Europa Scientific Ltd, Crewe, England) and was expressed as $\delta$ values (referring to the international standard Pee Dee Belemnite) as described earlier. ${ }^{20} 21$

Results are presented as $\delta$ over baseline values (DOB) and cumulative recovery after 12 hours. Cumulative recovery of the tracer dose in breath was calculated by multiplying the integrated enrichment time curve by the normal endogenous $\mathrm{CO}_{2}$ production ${ }^{21}$ assuming total $\mathrm{CO}_{2}$ production to be 300 $\mathrm{mmol} / \mathrm{m}^{2}$ surface area/h. Body surface area was calculated according to Haycock et al. ${ }^{22}$

\section{SECRETIN PANCREOZYMIN TEST}

The secretin pancreozymin test was performed after duodenal intubation with a Lagerlöf tube under fluoroscopic control as described previously. ${ }^{15} 23-25$ Stimulation was carried out by intravenous injection of $1 \mathrm{U} / \mathrm{kg}$ synthetic secretin (Secretolin, Hoechst, Frankfurt, Germany) and $1 \mathrm{U} / \mathrm{kg} \mathrm{CCK}-\mathrm{Pz}$ (Ferring Pharmaceuticals, Malmö, Sweden) 30 minutes later.

Duodenal aspirates were collected for $2 \times 15$ minutes (baseline), $2 \times 15$ minutes after secretolin, and $4 \times 15$ minutes after CCK-Pz with the subjects recumbent on their right side. This procedure overcomes the need of using a marker for recovery and acid contamination of duodenal aspirates is prevented by careful manual suction at the gastric port. ${ }^{24}$

All fractions were collected on ice and analysed immediately after sampling. Volume, bicarbonate concentration, and the activities of amylase, lipase (Monotest kit, Boehringer, Mannheim, Germany, with triolein as substrate), and trypsin (test kit, Boehringer, Mannheim, Germany, with benzoyl-arginine$p$-nitroanilide as substrate) were measured in each sample using established procedures..$^{25}$ In our laboratory, a lipase output $<65000$ U/30 $\min$ after CCK-Pz is abnormal.

FAECAL FAT ANALYSIS

Faecal fat analysis was performed by the van de Kamer method $^{16}$ or near infrared reflectance analysis, which give equivalent results in our laboratory. ${ }^{18}$ Stools were collected for 72 hours taking care that patients were on a diet containing about $100 \mathrm{~g}$ fat/day and that pancreatic enzymes were discontinued for $\geqslant$ four days before stool collection. Daily stool output was weighed, homogenised, and analysed separately, and mean daily output was calculated from the three day period. A faecal fat excretion $\geqslant 7 \mathrm{~g} /$ day represents steatorrhoea, whereas stool weight $>200 \mathrm{~g} /$ day is considered abnormal. ${ }^{4}$

\section{CALCULATIONS AND STATISTICS}

Results are presented as means (SEM). Statistical analysis (descriptive statistics, 95\% confidence intervals ( $95 \% \mathrm{CIs}$ ), analysis of variance with Bonferroni multiple comparison correction, and curve fitting) was performed with the software program PRISM (version 1.0 , GraphPad, San Diego, USA). A p value $<0.05$ was considered significant.

\section{Results}

The cumulative ${ }^{13} \mathrm{C}$ recovery 12 hours after the test meal displayed a linear and significant correlation with peak $\delta$ over baseline responses $\left(\mathrm{DOB}_{\max }\right)$ according to the equation:

$$
\begin{gathered}
\mathrm{Y}=1 \cdot 42 \pm 0 \cdot 12 \mathrm{X}+9 \cdot 13 \pm 3 \cdot 50 \\
(r=0 \cdot 859 ; \mathrm{p}<0 \cdot 0001 ; \mathrm{n}=50, \text { Fig } 1)
\end{gathered}
$$

$\mathrm{DOB}_{\max }$-responses were not significantly different between healthy controls (53.9 (5.1) $\delta \%$; group IV), patients with normal pancreatic function without steatorrhoea $(50.2(3.0) \delta \%$, group III), and patients with exocrine pancreatic insufficiency without steatorrhoea $(51.0(3.0) \delta \%$, group II). The lower $95 \% \mathrm{CI}$ of the control group was $41 \cdot 4 \delta \%$.

$\mathrm{DOB}_{\max }$ responses in group I patients (pancreatic steatorrhoea), however, were significantly lower than in any other group 


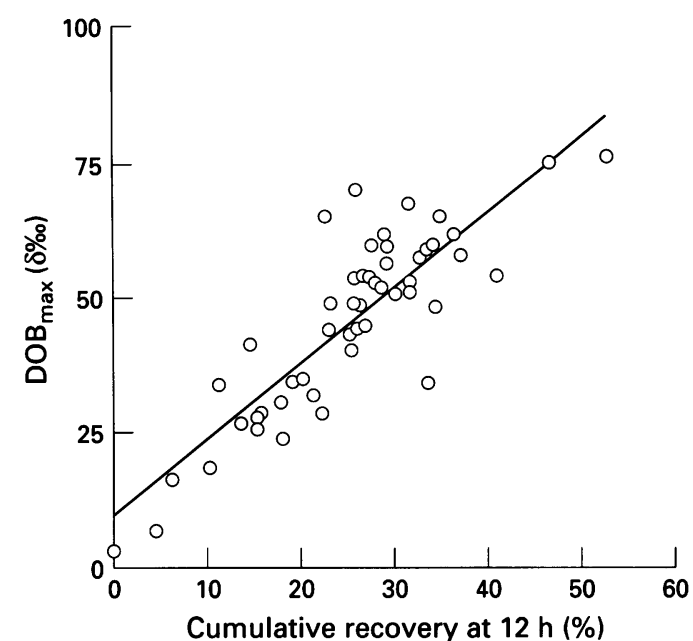

Figure 1: Correlation of the cumulative recovery at 12 hours after Hiolein ingestion (\% of dose administered) with peak $\delta$ over baseline ${ }^{13} \mathrm{CO}_{2}$ responses $\left(D O B_{\max }, \delta \%\right.$ ) .

tested $(\mathrm{p}<0.001$ compared with groups II, III, and IV; $\mathrm{p}<0.01$ compared with group V; Bonferroni multiple comparisons test).

Because of the multiple comparisons and the limited number of patients, the difference in
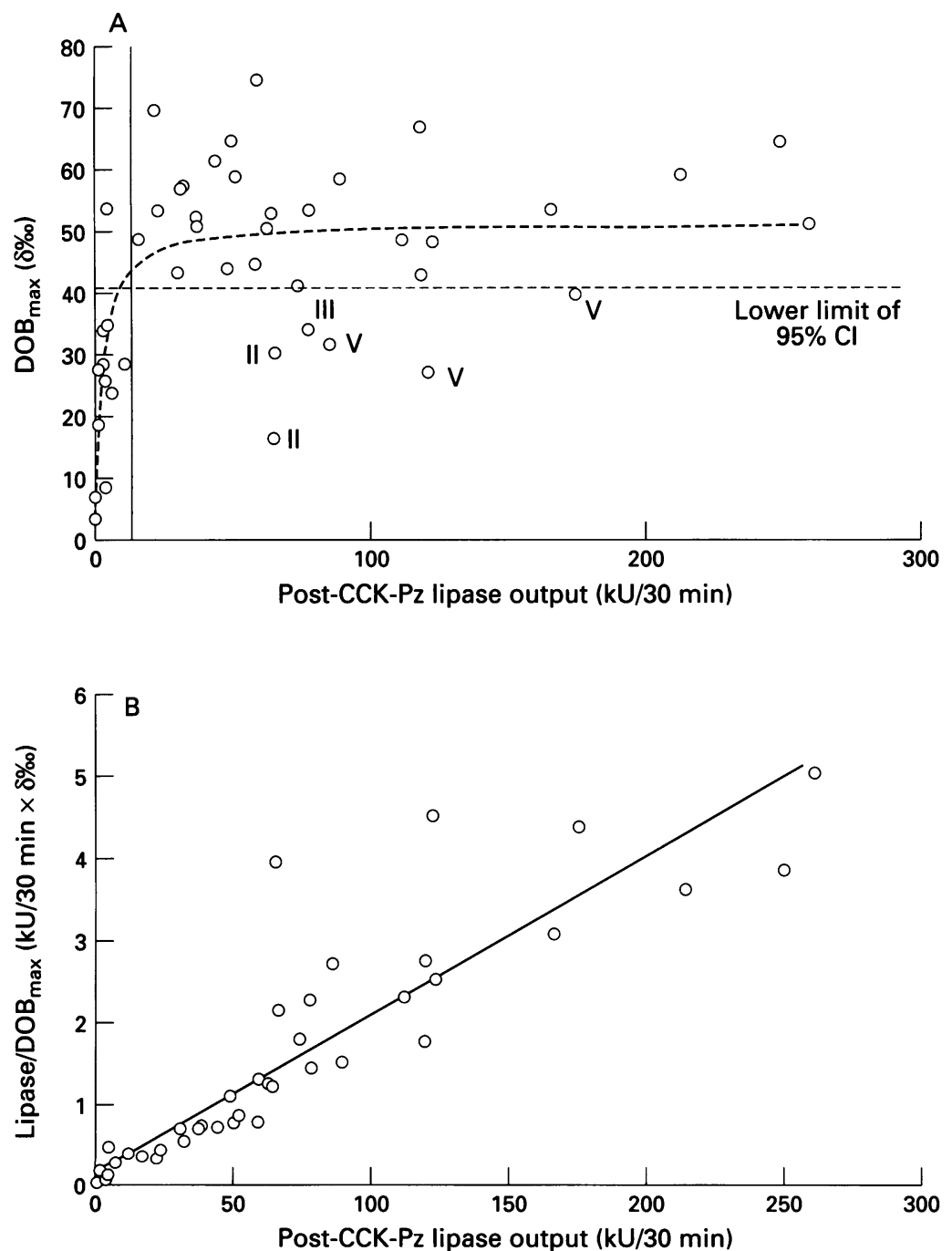

Figure 3: (A) Hyperbolic correlation of peak $\delta$ over baseline responses (DOB ${ }_{\max }, \delta \%$ ) with stimulated duodenal lipase output ( 30 minutes) after $C C K-P z$. The horizontal dotted line indicates the lower limit of normal (95\% CI used as the cut off), the vertical line indicates $10 \%$ residual lipase secretion (after $12000 \mathrm{U} / 30 \mathrm{~min}$ ). The respective groups are given for those patients with low $D O B_{\max }$ responses despite less severely reduced or normal lipase output. (B) Transformation of the data (stimulated duodenal lipase output/30 min/DOB $B_{\max }$ $v$ stimulated duodenal lipase output/30 min) shows linearity $(r=0.95)$, which corroborates the hyperbolic curve fitting in Fig $3 A$.

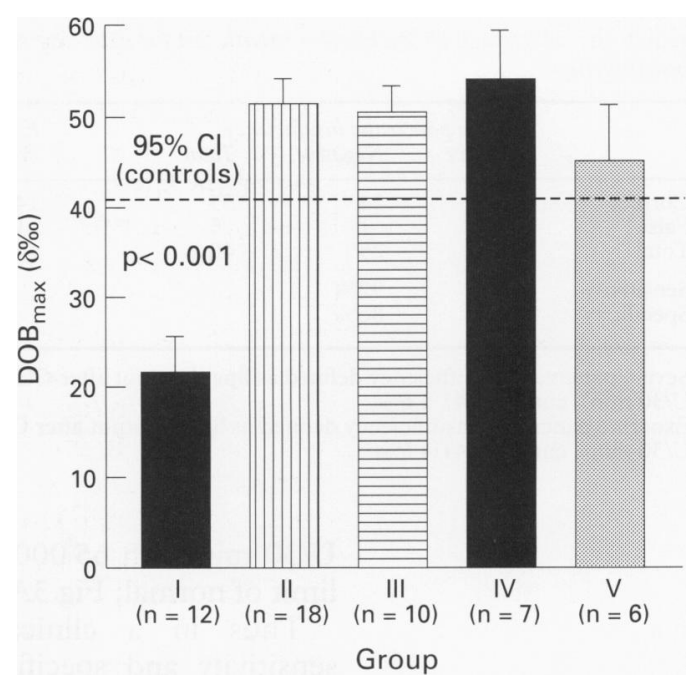

Figure 2: Peak $\delta$ over baseline responses $\left(D O B_{\max }, \delta \% \circ\right)$ in patients with pancreatic steatorrhoea (group I), exocrine pancreatic insufficiency without steatorrhoea (group II), patients without exocrine pancreatic insufficiency and without steatorrhoea (group III), normal controls (group IV), and disease controls (non-pancreatic steatorrhoea, group V). DOB $B_{\max }$ responses are significantly diminished in group I ( $p<0.001$ compared with any other group). The dotted line refers to the lower limit of the $95 \%$ CI of the controls (group IV). The reduction of $D O B_{\max }$ responses in group $V$ is not significant ( $v$ controls).

$\mathrm{DOB}_{\max }$ responses in the six patients with nonpancreatic steatorrhoea $(44 \cdot 9(6 \cdot 1) \delta \%$ ) was not significant compared with the controls (Fig 2).

The relation of $\mathrm{DOB}_{\max }$ responses to the duodenal lipase output after stimulation of the pancreas with CCK-Pz was assessed in the 46 patients who underwent a secretinpancreozymin test (Fig 3A). With only one exception (carcinoma of the pancreas), all patients with a post-CCK-Pz lipase output $<12000 \mathrm{U} / 30 \mathrm{~min}$ ( $<10 \%$ of the mean normal lipase output) had $\mathrm{DOB}_{\max }$ responses $<41.4$ $\delta \%$ (the lower $95 \%$ CI of the controls).

Of the other six patients with low $\mathrm{DOB}_{\max }$ responses, two had exocrine pancreatic insufficiency without steatorrhoea (one of them with an abnormal starch $\mathrm{H}_{2}$ breath test $(40 \mathrm{ppm})$ ), one patient (group III, also with a positive $\mathrm{H}_{2}$ breath test (40 ppm)) had chronic pancreatitis coincident with liver cirrhosis and diabetes mellitus, and the remaining three patients belonged to group V (non-pancreatic steatorrhoea).

Among the 40 patients with suspected pancreatic disease (groups I-III) - that is, those in whom pancreatic function tests were clinically indicated $-\mathrm{DOB}_{\max }$ responses were correctly positive $(<41 \cdot 1 \delta \%$ ) in 12 patients with a lipase output $<12000 \mathrm{U} / 30 \mathrm{~min}$ (11 of them with pancreatic steatorrhoea). One false negative DOB result was found in a patient with pancreatic carcinoma. False positive results (with reference to lipase) were obtained in three patients. Two of these patients (one with chronic pancreatitis and one with chronic pancreatitis combined with diabetes mellitus and cirrhosis of the liver) had an abnormal breath $\mathrm{H}_{2}$ test indicating additional causes of malabsorption. Furthermore, the post-CCK$\mathrm{Pz}$ lipase output was borderline in two of the three false positive tests (64 106 and 64549 
TABLE III Accuracy of the Hiolein breath test for detecting severe and exocrine pancreatic insufficiency

\begin{tabular}{lcccccc}
\hline & \multicolumn{3}{c}{ Severe pancreatic insufficiency } & \multicolumn{3}{c}{ Exocrine pancreatic insufficiency } \\
& Positive & Negative & Total & Positive & Negative & Total \\
\hline Correct & 11 & 24 & 35 & 14 & 9 & 23 \\
False & 4 & 1 & 5 & 1 & 16 & 17 \\
Total & 15 & 25 & 40 & 15 & 25 & 40 \\
Sensitivity & & $92 \%$ & & & $47 \%$ & \\
Specificity & & $86 \%$ & & & $90 \%$ &
\end{tabular}

Severe pancreatic insufficiency defined as lipase output after CCK-Pz $<10 \%$ of normal $(12000$ $\mathrm{U} / 30 \mathrm{~min}$ ), cut off at $41.4 \mathrm{\delta} \%$

Exocrine pancreatic insufficiency defined as lipase output after CCK-Pz abnormal $(<65000$

U/30 min), cut off at $41.4 \delta \%$.

$\mathrm{U} / 30 \mathrm{~min}$ with $65000 \mathrm{U} / 30 \mathrm{~min}$ as the lower limit of normal; Fig 3A).

Thus in a clinically relevant scenario, sensitivity and specificity of the ${ }^{13} \mathrm{C}$-Hiolein breath test for detecting pancreatic steatorrhoea were $91 \cdot 7 \%$ and $85 \cdot 7 \%$, respectively (cut off at $41 \cdot 4 \delta \% \mathrm{DOB}_{\max }$, Table III).

The correlation of $\mathrm{DOB}_{\max }$ versus lipase output after stimulation was characterised by a hyperbolic function $(\mathrm{Y}=\mathrm{mX} /(\mathrm{k}+\mathrm{X})$, constants
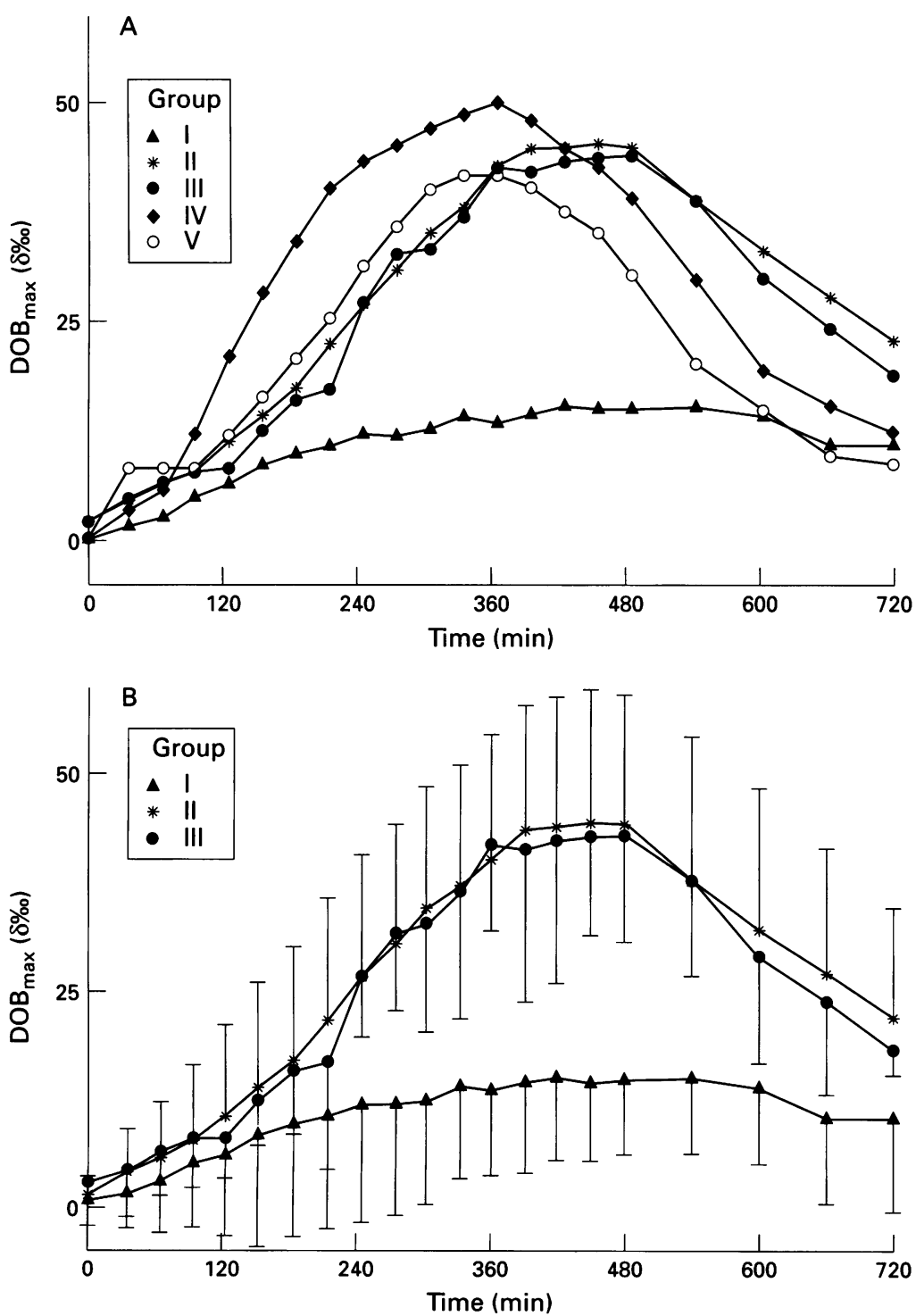

Figure 4: Time course of the ${ }^{13} \mathrm{CO}_{2}$ response after Hiolein ingestion. (A) Mean values, groups I-V. (I) Pancreatic steatorrhoea, (II) exocrine pancreatic insufficiency without steatorrhoea, (III) patients with normal pancreatic function, (IV) normal controls, (V) non-pancreatic steatorrhoea. (B) Mean (SD) values in patients with suspected (group III) and confirmed (groups I, II) pancreatic disease. Peak times are almost identical (see also Fig 5).

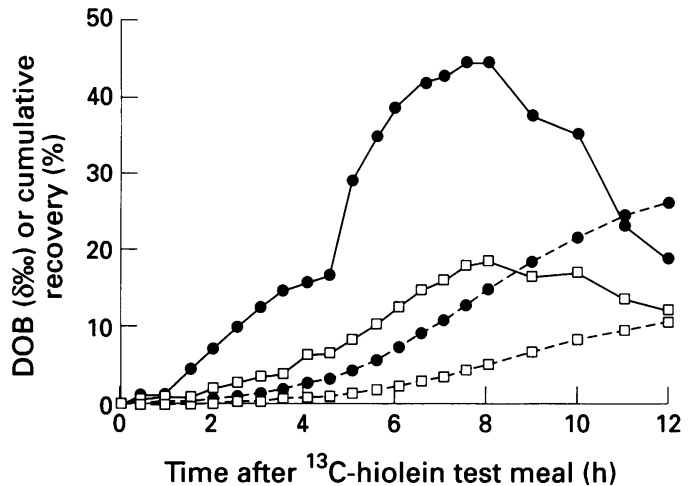

Figure 5: Effect of high dose pancreatin supplementation (Kreon micropellets, $80000 \mathrm{U}$ lipase given with the test meal) on the DOB responses (straight lines) and

cumulative recovery of ${ }^{13} \mathrm{C}$ (dotted lines) in one patient with pancreatic steatorrhoea. (ㅁ) Without pancreatin; (๑) with pancreatin supplementation.

$\mathrm{m}=51 \cdot 34(2 \cdot 64)(95 \%$ CI $46 \cdot 01-56 \cdot 67)$ and $\mathrm{k}=2 \cdot 30(0 \cdot 89)(95 \%$ CI $0 \cdot 51-4 \cdot 09), r=0 \cdot 702$;

Fig 3A).

Plotting lipase/DOB $\mathrm{Dax}_{\max }$ versus lipase output (Fig 3B) yielded a linear curve fit $(\mathrm{Y}=0.021$ $(95 \%$ CI $0.019-0.023) \pm 0.001 \quad \mathrm{X} ; \mathrm{r}=0.949$ $(\mathrm{p}<0.0001))$.

Peak maxima of the DOB responses occurred six to nine hours after ingestion of the labelled test meal (Fig 4A, B), showing that a more feasible sampling period of eight hours would be sufficient. Although not significant, patients with malabsorption (group V) and the controls (group IV, comprising more females and younger subjects that the 'target' groups of patients with pancreatic disease) tended towards slightly earlier $\mathrm{DOB}_{\max }$ responses.

However, testing the effect of high dose pancreatin supplementation (Kreon micropellets, Kali Chemie, Hannover, Germany; single dose of $80000 \mathrm{U}$ lipase with the test meal) in one patient of group I with a grossly abnormal DOB response (Fig 5), showed that pancreatin may restore the ${ }^{13} \mathrm{CO}_{2} /{ }^{12} \mathrm{CO}_{2}$ response to normal but does not accelerate the time of peak occurrence $\left(\mathrm{DOB}_{\max }\right)$.

\section{Discussion}

Breath tests are clinically feasible methods for assessing pancreatic dysfunction, because they do not require stool or urine collection (which is often incomplete) and because they are noninvasive. Compared with former breath tests using ${ }^{14} \mathrm{C}$ labelled substrates (triglycerides), breath tests using the stable isotope ${ }^{13} \mathrm{C}$ as a label have the additional advantage of being non-radioactive.

Another potential advantage of the [U- $\left.{ }^{13} \mathrm{C}-\right]$ Hiolein breath test, which behaves like triolein $^{13}$ is the use of only trace amounts of a nutritionally relevant substrate - that is, physiologically ingested long chain triglycerides (Table I).

Vantrappen et al have shown that another ${ }^{13} \mathrm{C}$-mixed triglyceride test may reflect duodenal lipase activity. This molecule bears the ${ }^{13} \mathrm{C}$ label at the carboxy $\mathrm{C}$ atom of the medium chain fatty acid at $\mathrm{C} 2$ of the glycerol moiety ( ${ }^{13} \mathrm{C}$-octanoate). However, whereas 
liberation of this substrate is dependent on duodenal lipolytic activity, and the use of octanoate ensures rapid oxidation, the test lipid applied is not a normal constituent of food. ${ }^{11}$

Another substrate with rapid oxidation (peak maximum at 90-120 minutes) used for assessing pancreatic function by a breath test is ${ }^{13} \mathrm{C}$-cholesteryl octanoate. ${ }^{96}$ This compound is not a substrate for classic pancreatic lipase activity but for cholesterol esterase. It is not hydrolysed by lingual or by gastric lipase. Therefore, monitoring of therapeutic lipase supplementation may give results that are different from a system which recognises these contributions (such as labelled triolein).

Evaluating the clinical validity and potential of the non-invasive and non-radioactive ${ }^{13} \mathrm{C}$-Hiolein breath test, we have shown that $\mathrm{DOB}_{\max }$-responses of the breath ${ }^{13} \mathrm{CO}_{2} /{ }^{12} \mathrm{CO}_{2}$ ratio accurately reflect duodenal lipolytic activity after stimulation with $\mathrm{CCK}-\mathrm{Pz}$ in patients with exocrine pancreatic insufficiency of different severities.

This correlation is not linear but hyperbolic, a finding that is confounded by the known correlation between lipase output after CCK$\mathrm{Pz}$ and steatorrhoea ${ }^{5}$ as well as by results obtained with other breath tests for impaired lipolysis ${ }^{911}$ or impaired amylase output. ${ }^{14}$

Because pancreatic steatorrhoea is restricted to patients with severely impaired lipase output $(<10 \%$ of normal - that is, $<12000 \mathrm{U} / 30$ min), a significant reduction of $\mathrm{DOB}_{\max }{ }^{-}$ responses was only found in patients with pancreatic steatorrhoea (Fig 2). The Hiolein breath test thus distinguished two groups of patients: those with a stimulated lipase output below the cut off at $10 \%$ of normal and patients with less (or no) functional impairment.

Focusing on diagnosing or monitoring pancreatic steatorrhoea, sensitivity $(92 \%)$ and specificity $(86 \%)$ of the ${ }^{13} \mathrm{CO}_{2}$-Hiolein breath test were well acceptable with the diagnostic cut off at $41.4 \delta \%$. These results are comparable with those obtained with radioactive triolein. ${ }^{7}$

However, the breath test did not detect mild or moderate forms of exocrine pancreatic dysfunction without steatorrhoea - that is, patients with a reduced duodenal lipase output after stimulation with CCK-Pz (12000$65000 \mathrm{U} / 30 \mathrm{~min})$, resulting in an overall sensitivity of only $46 \cdot 7 \%$ (specificity $90 \%$ ) for diagnosing exocrine pancreatic insufficiency (lipase $<65000 \mathrm{U} / 30 \mathrm{~min}$ after CCK-Pz).

Because of the non-linear (hyperbolic) correlation between lipase output and the malassimilation of fat, this finding is not regarded as reflecting insensitivity of the new breath test. Rather it is the consequence of the physiological ('true') relation between lipase output and fat digestion.

Therefore, as with faecal fat analysis, we would not expect any fat absorption test principle to diagnose mild to moderate degrees of exocrine pancreatic insufficiency with clinically acceptable accuracy. ${ }^{7-9}$

By contrast, more graded responses of lipolysis $\left({ }^{13} \mathrm{CO}_{2}\right.$ enrichment in the breath) to the pancreatic lipase output have been found by Vantrappen et $a l^{11}$ with the mixed triglyceride breath test resulting in a substantially better sensitivity $(0 \cdot 81)$ for the detection of pancreatic insufficiency. As this study used a similar amount of unlabelled fat, this implies that impaired lipolysis was detected at stages of exocrine pancreatic insufficiency when overall fat absorption was still complete. This test may therefore be more vulnerable regarding false positive results in cases of malabsorption.

Our data show that the ${ }^{13} \mathrm{C}$-Hiolein breath test is a valid test for pancreatic steatorrhoea but does not reflect pancreatic function unless decompensation (steatorrhoea) occurs. Consequently, the clinical value of the Hiolein test is primarily targeted at diagnosing the patient who requires pancreatin therapy and to monitor the efficacy of enzyme supplementation (Fig 5), similar to faecal fat analysis.

Newer modifications of faecal fat analysis based on near infrared reflectance analysis allow a more convenient and acceptable quantitative analysis of pancreatic steatorrhoea than the van de Kamer method. Inadequate stool collection, however, can still render faecal fat analysis potentially misleading. ${ }^{17} 18$

Therefore, a valid, clean, and feasible method both for detecting pancreatic steatorrhoea and monitoring enzyme replacement therapy may be advantageous in a clinical setting.

Because the fatty acids of Hiolein have their oxidation peak at six to nine hours, a second measurement eight hours after substrate ingestion may be adequate and sufficient.

Isotope ratio measurements without mass spectrometry (for example, non-dispersive isotope selective infrared analysis), ${ }^{27}$ and established logistics for isotope ratio mass spectrometry on an outpatient base are recent important developments, which will help to promote stable isotope breath tests in gastroenterology as a routine clinical application. In malnourished paediatric patients - for example, in cystic fibrosis - the ${ }^{13} \mathrm{C}$-Hiolein breath test may be used as an accurate and convenient measure of pancreatic steatorrhoea (Braden et al, unpublished observations).

Part of this work has been presented in abstract form at the 48th Annual Meeting of the Deutsche Gesellschaft für Verdauungsund Stoffwechselkrankheiten, Frankfurt, September 1993 ( $Z$ Gastroenterol 1993; 31: 543 A).

The work was made possible through a grant from the ElseKröner-Fresenius Foundation. BL was supported for a sabbatical leave by the Deutsche Gesellschaft für Verdauungsund Stoffwechselkrankheiten (DGVS), Asche grant 1991. We und Stoffwechselkrankheiten (DGVS), Asche grant 1991. We thank J Delente, Martek Corporation, Columbia, MD 21045,
USA for assisting us with the supply of ${ }^{13} \mathrm{C}$-Hiolein and $\mathrm{Dr}$ USA for assisting us with the supply of ${ }^{13} \mathrm{C}-$ Hiolein and
Oliver Ottmann for his help in reviewing the manuscript.

1 Toskes PP. Chronic pancreatitis. Current Opinion in Gastroenterology 1993; 9: 767-73.

2 Niederau C, Grendell JH. Diagnosis of chronic pancreatitis. Gastroenterology 1985; 88: 1973-95.

3 Lankisch PG. Progress report: exocrine pancreatic function tests. Gut 1982; 23: 777-98.

4 Lembcke B, Braden B, Stein J. Diagnostik der Steatorrhoe (diagnosing steatorrhoea). Z Gastroenterol 1994; 32: 256-61.

5 DiMagno EP, Go VWL, Summerskill WHJ. Relations between pancreatic enzyme outputs and malabsorption in severe pancreatic insufficiency. $N$ Engl f Med 1973; 288: 813-5. 
6 Lankisch PG, Otto J, Brauneis J, Hilgers R, Lembcke B. Detection of pancreatic steatorrhoea by oral pancreatic function tests. Dig Dis Sci 1988; 33: 1233-6.

7 Newcomer AD, Hofmann AF, DiMagno EP, Thomas PJ, Carlson GL. Triolein breath test. A sensitive and specific test for fat malabsorption. Gastroenterology 1979; 76: $6-13$.

8 Ghoos YF, Vantrappen GR, Rutgeerts PJ, Schurmans PC. A mixed triglyceride breath test for intraluminal fat A mixed triglyceride breath test for intra

9 Cole SG, Rossi S, Stern A, Hofmann AF. The cholesteryl octanoate breath test. Preliminary studies on a new noninvasive test of human pancreatic exocrine function. Gastroenterology 1987; 93: 1372-80.

10 Watkins JB, Klein PD, Schoeller DA, Kirschner BS, Park R, Perman JA. Dianosis and differentiation of fat malabsorption in children using ${ }^{13} \mathrm{C}$-labeled lipids: trioctanoin, triolein, and palmitic acid breath tests. Gastroenterology 1982; 82: 911-7.

11 Vantrappen GR, Rutgeerts PJ, Ghoos YF, Hiele MI. Mixed triglyceride breath test of pancreatic lipase activity in the duodenum Gastroenterology 1989; 96: 1126-34.

12 Murphy MS, Eastham EJ, Nelson R, Aynsley-Green A. Non-invasive assessment of intraluminal lipolysis using a Non-invasive assessment of intraluminal lipolysis usin
${ }^{13} \mathrm{CO}_{2}$ breath test. Arch Dis Child 1990; 65: 574-8.

13 Klein PD, Hachey DL, Opekun AR, Tacquard PE, Kyle D. Oxidation studies of a biosynthetic randomly ${ }^{13} \mathrm{C}$-labeled Oxidation studies of a biosynthetic randomly
triglyceride. Gastroenterology 1991; 100: 528 A.

14 Hiele M, Ghoos Y, Rutgeerts P, Vantrappen G. Starch digestion in normal subjects and patients with pancreatic disease, using a ${ }^{13} \mathrm{CO}_{2}$ breath test. Gastroenterology 1989; 96: 503-9.

15 Lankisch PG. Secretin test or secretin-CCK test - gold standard in pancreatic function testing? In: Gyr $\mathrm{KE}$, Singer MV, Sarles H, eds. Pancreatitis - concepts and classification. Amsterdam: Exerpta Medica, 1984: 247-59.

16 van de Kamer JH, Huinik HB, Weyers HA. Rapid method for the determination of fat in feces. $\mathcal{F}$ Biol Chem 1949; 2: $347-55$.
17 Benini L, Caliari S, Guidi GC, Vaona B, Talamini G, Vantini I, Scuro LA. Near infrared spectroscopy for faecal measurement: comparison with conventional gravimetric and titrimetric methods. Gut 1989; 30: 1344-7.

18 Stein J, Purschian B, Bieniek U, Caspary WF, Lembcke B. Near infrared reflectance analysis (NIRA): A new dimension in the investigation of malabsorption

syndromes. Eur f Gastroenterol Hepatol 1994; 6: 889-94.
9 Kerlin P, Wong L, Harris B, Capra S. Rice flour, breath hydrogen, and malabsorption. Gastroenterology 1984;87: hydrogen,

20 Mook WG, Grootes PM. The measuring procedure and corrections for high-precision mass spectrometric analysis of isotopic abundance ratios, especially referring to carbon, oxygen and nitrogen. International fournal of Mass Spectroscopy and Ion Physics 1973; 12: 273-98.

21 Braden B, Adam S, Duan LP, et al. ${ }^{13} \mathrm{C}$-acetate breath test accurately reflects gastric emptying of liquids both in liquid and semisolid test meals. Gastroenterology 1995; 108: 1048-55.

22 Haycock G, Schwartz G, Wisotsky D. Geometric method for measuring body surface area: a height-weight formula validated in children and adults. $\mathcal{f}$ Pediatr 1978; 93: $62-6$.

23 Creutzfeldt W. Funktionsdiagnostik bei Erkrankungen des exokrinen Pankreas. Verhandlungen der Deutschen exokrinen Pankreas. Verhandlungen der Deut

24 Lankisch PG, Creutzfeldt W. Effect of synthetic and natural secretin on the function of the exocrine pancreas in man. Digestion 1981; 22: 61-5.

25 Lankisch PG, Brauneis J, Otto J, Göke B. Pancreolauryl and NBT-PABA tests. Gastroenterology 1986; 90: 350-4.

26 Mundlos S, Kühnelt P, Adler G. Monitoring enzyme replacement in exocrine pancreatic insufficiency using the cholesteryl octanoate breath test. Gut 1990; 31: 1324-8.

27 Braden B, Haisch M, Duan LP, Lembcke B, Caspary WF, Hering P. Clinically feasible stable isotope technique at a Hering $P$. Clice reason infrared spectrometer. $Z$ Gastroenterol 1994; 32: 675-78. 